\title{
Castrated Female
}

National Cancer Institute

\section{Source}

National Cancer Institute. Castrated Female. NCI Thesaurus. Code C54014.

A female individual who has had her ovaries removed. 